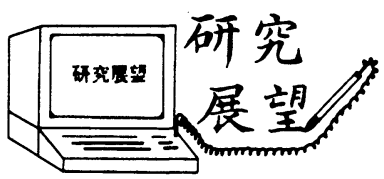

日本機械学会論文集 $(\mathrm{C}$ 編)

74 巻 737 号 $(2008-1)$

歯車設計の曖昧部分と対処策*

松本

將*1

\title{
Ambiguity in Gear Design and Countermeasures
}

\author{
Susumu MATSUMOTO*2
}

*2 The Graduate School of Information, Production and Systems, Waseda University, 2-7 Hibikino, Wakamatsu-ku, Kitakyushu-shi, Fukuoka, 808-0135 Japan

Key Words: Gears, Gear Design, Gear Technology, Power Transmission, Gear Failure, Tooth Root Bending Strength, Tooth Surface Durability, Power Loss, Gear Vibration

\section{1. はじめに}

歯車設計は規格化され摇るぎないものと信じている 設計者が多い. 損傷トラブルに遭遇して, 規格を遵守 しなかったから起こったと反省する。しかし規格に従 った設計を行っても，損傷トラブルに見舞われる場合 は多い。その理由は歯車の損傷発生メカニズムが完全 に解明されていないため, 歯車の使用限界と損傷発生 に対する認識, 損傷への影響因子の理解が十分でない ことによる.さらに歯車損傷や振動騒音, 動力損失に 対する定量的なトラブル末然防止策の欠如が, 設計の 曖昧さとなっている. 本稿では著者の経験を中心に歯 車設計を行う際に留意すべき事項を述べ，その解決が 今後必要とされる研究課題であることを示す。

\section{2. 歯車装置強度設計手順の暧昧部分}

$2 \cdot 1$ 設計コンセプトの曖昧部分 周知のように, 規格設計(1) (7) の場合は簡易式や設計図表を基に作業 が進む.その各手順段階に応じて歯当たり解析や振動 解析などを行い詳細設計としてとりまとめていくく ${ }^{(8)}$. 設計の解析で得た負荷や応力值と損傷発生限界値とを 対比し一義的に成否を決め, 多くの場合は限界値と発 生応力值の比を安全率として設計成否を決めるカテゴ リー設計が行われている。

歯車装置の設計で最も曖昧な点は, 安全率と損傷発 生確率の関係である. 歯車にかかる応力および応力に 対比する強度は分布をもっている. 材料強度に確率分

\footnotetext{
* 原稿受付 2007 年 8 月 22 日.

*1 正員, フェロー, 早稲田大学大学院情報生産システム研究科 (『808-0135 北九州市若松区ひびきの 2-7).

E-mail : su_matsumoto@ waseda.jp
}

布があるのは周知のこと(9)であるが, このコンセプト が十分に歯車設計に取り込まれていないため, 安全率 がある程度あれば損傷は生じないという設計が実際に 行われている場合が多い. したがって，ある安全率を 確保すれば, 歯車は壊れないとの妄信が歯車装置寿命 への過信となり, 歯車装置長期間使用後の損傷も歯車 メーカの暇疵(かし)とされている. 歯車設計者もこれ はおかしいと感じながらも, 定量的な対処ができない のが現状である。

機械設備の信頼度確保のためには, 設備を構成する 各部品の信頼度や損傷発生確率を知る必要がある. 歯 車装置は単独では存在意義のない補機であるため, 歯 車装置単独の寿命とリスクは, 歯車装置を使う設備の 寿命とリスクに含めて考えられる. そのためには, 他 の部品や要素と同様に損傷発生確率とリスクを表現す る必要性が高まっている。

$2 \cdot 2$ 曖昧部分への対処策 転がり軸受は確率寿 命計算を行う社会的コンセンサスがある．寿命予測精 度に疑わしい点は多いが, 歯車とは異なる技術体系が ある．同じ転動要素である歯車も本質的には同様の表 現が可能である。歯車装置の寿命が疲労限以下で無限 寿命であるような業界の認識を一新しなければ, 歯車 製造側はずっと損傷のリスクを負い続けなければなら ない.

この現状を打破するためには疲労寿命を表す SN 線図を損傷発生確率ごとに把握する必要があるが, 使 いやすい損傷発生確率を考慮した応力・繰返し数線図 (PSN 線図) はない. 現実的な対処としては日本機械 学会 RC 調査研究分科会にて, 歯元曲げ疲労折損と歯 面ピッチングに関しての PSN 線図が提案された ${ }^{(10)}$. 提案ではこれまで発表された疲労デー夕を統計的に処 
理し, 応力値と応力繰返し数から損傷発生確率を求め るようになっている．数多くの異なった実験結果を一 括処理しているため線図の精度は良くないが, 歯車確 率設計のための考え方と線図(影響因子)が示された意 義は大きい. 今後の歯車技術向上のためには, 線図の 精度向上が必須である.

\section{3. 損傷発生限界の曖昧部分と対処}

\section{$3 \cdot 1$ 使用限界}

〈設計の現状〉歯車の損傷発生と使用限界の区別が 曖昧である. 歯面の疲労ピットや歯元折損を考えた場 合, 損傷はまず歯車を構成する複数の歯の一部, 場合 によっては 1 枚に生じる。その損傷が進展して, 他の 歯にも損傷が生じていく，一般的には，最初に生じた 歯の損傷および継続して損傷が生じた歯の損傷程度が 進行して, 振動や騒音の増加で損傷発生を認識する. しかし, 損傷発生により運転に伴う振動值が増加して も，歯車の使用を継続する場合も多い.

〈対処〉「使用限界」として, 歯車装置の運転が困 難となった状態と定義すれば, 多くの損傷はただちに 限界にはならない。.また同じ損傷状態でも, 歯車装置 の使用目的により「損傷」と「許容(使用限界)」に判 断が分かれる。例えば歯面ピッチングが生じても装置 の振動や騒音に影響ないとすれば, ピッチング損傷の 進展を許容し，ピッチング面積率の増加で使用限界を 判断する. 損傷が生じても運転を続ける場合は, 運転 リスクが生じる，その場合は「損傷レベル」(損傷の 激しさ)と, 「歯車装置を用いている機器への影響の 大きさ」をそれぞれ三段階程度に評価し，それぞれの 積が, $1 \sim 2:$ 運転継続, $3 \sim 5:$ 注意運転(いつでも停 止), 6 9: 即刻停止, 装置交換などの処置を考える.

$3 \cdot 2$ 歯面転動疲労損傷 歯面転動疲労損傷の定 義が暧昧である. 厳密には疲労ピットの最初の 1 個が 生じる時点に意味があるが, 実際にはそのピットの大 きさなどの定義がない.き裂表面起点型のピッチン グ, 内部起点形のスポーリングなどは頻繁に歯面の観 察を行わねば, 最初のピットを確認することが困難で ある。

\section{$3 \cdot 2 \cdot 1$ 発生限界}

〈設計の現状〉 ピッチング損傷発生限界が示されて いるが，そこで発生する損傷がどのようなものか, 規 定されていない. 1 個のピットの発生と面積率で $2 \%$ の多くのピットの発生は, 明らかに限界が異なるはず であるのに，あえてその違いが示されていない.ピッ チング面積率は損傷の程度であり, 使用限界として考 えねばならない.
〈対処〉使用限界の認識は実際の機械では重要であ る.ピットが複数生じても, 歯車の運転挙動にほとん ぞ影響はない. しかし，その損傷が突発的破壊の兆候 であれば，運転状態が正常でも運転停止すべきであ る. 特に発生き裂の進展が大きな破壊につながりやす い表面硬化歯車では, 少数のピットを限界とすること も必要である。調質鋼の場合は歯面損傷が致命的破壊 になりにくいので, 損傷程度の進展と振動の増加など をよく観察して対処する。ピッチング進展の有無は, 継続的な歯面観察以外に知る方法がないので, 現実的 には様子を見続けるしかない.

$3 \cdot 2 \cdot 2$ 疲労限の有無

〈設計の現状〉転動疲労の疲労限の有無が曖昧であ る. 転がり軸受は疲労限がないことで,つねに有限寿 命設計になっている.

〈対処〉歯車も転がり軸受と同じ転動要素であり, 疲労限が存在しないと考えたほうが安全である. 修正 マイナー則のように有限寿命を考えていく.

$3 \cdot 2 \cdot 3$ 損傷発生確率が不明

〈設計の現状〉損傷発生限界が何\%の損傷発生確率 に刘応しているのか不明である. 設計者は SN 曲線 をカテゴリー分けの境界線と考元, 多くの場合は線よ りも少しでも下になるように接触応力を考える.

〈対処〉PSN 線図はすぐには完備しない. 前述し たような日本機械学会の提案を待つまでもなく, 自社 製品の使用条件と損傷確率の関係を整理し, 設計を行 っていかねばならない. PSN 線図を短時間に作成す る方法として, 歯車の歯 1 枚を 1 サンプルとして, 何 枚の歯に損傷が出るかを実験的に調べれば, 同一荷重 での歯数分の損傷発生確率は求まる。さらに歯すじを 片当たりさせ, 歯すじ方向に接触圧力分布を発生させ れば一対の歯車試験で, 異なった接触圧力の試験が行 え SN 曲線を作成することができる(11). 歯車 PSN 曲 線の迅速な作成方法として, 今後の検討が待たれる.

$3 \cdot 3$ 歯の折損損傷 歯の折損には, 繰返し応力 による歯元曲げ疲労と, ピッチングや歯形干渉で生じ たき裂が起点となる歯面起点折損がある.

$3 \cdot 3 \cdot 1$ 歯元曲げ疲労限の有無

〈設計の現状〉＼cjkstart単純なはりの曲げと考えれば, 曲げ 疲労限界は存在し, 限界以下の曲げ応力では無限回の 繰返し数に耐えるとされている。

〈対処〉歯元曲げ疲労の場合は疲労限が存在すると 考えられる.しかし, 歯車の歯の疲労限は, 損傷発生 確率に応じた曲げ応力値が存在する(10) ので, 損傷発 生確率に応じた許容曲げ応力値としていく. 
$3 \cdot 3 \cdot 2$ 疲労限以上の応力での時間寿命

〈設計の現状〉 マイナー則による累積被害則 ${ }^{(12)}$ が 成立すると考えられている。

〈対処〉負荷と応力繰返し数が変動する自動車用歯 車などの疲労寿命検討手法として定着しているが, 累 積被害則の成否はよく実証されていない.しかし有限 寿命と考えれば安全側の対処になる.

$3 \cdot 3 \cdot 3$ 歯元隅肉部曲率半径と疲労限の関係 〈設計の現状〉最近 FEM 計算などで歯元隅肉部の 最大応力部分を求め設計に使用する場合が多い(13). 応力集中係数として考え, 曲げ疲労データの整理に用 いられている．しかし材料の疲労に及ほす応力集中の 影響は，切欠係数として対処すべきである(14). 歯元隅 肉部曲率半径が小さい場合には, 切欠感度係数の影響 が出てくるために, 応力集中した応力値で疲労限を表 現すると異常に高い応力值が設計限界とされる危険が ある。

〈対処〉新しい知見ではないが，切欠感度係数の概 念を歯車設計に導入していく．特に小モジュール歯車 では重要な設計事項になる。

$3 \cdot 3 \cdot 4$ 歯面起点曲げ折損

〈設計の現状〉歯面損傷がなければ歯面起点折損は 起こらない. また歯面損傷が起こる条件であっても， 折損起点を事前に予想することは困難である。

〈対処〉歯面損傷からの破損は, 表面硬化の場合が 折損に至りやすい. したがって，表面硬化歯車では歯 面損傷が折損損傷の前兆と認識すべきである. 一方, 調質鋼歯車では歯面にピッチングが生じても，折損の 危険は少ない.したがって, 調質鋼歯車ではピッチン グの進展に伴う動的増加荷重(振動) と摩耗に伴う歯厚 の減少に留意しておく.

3・4 歯面焼付き 歯面の焼付きの定義が曖昧で ある、スコーリングあるいはスカッフィング損傷は焼 付いた結果の歯面状況を表すが, 程度の軽重, 焼付き 範囲などの定義がはっきりしない. 最近日本機械学会 から出版された歯車損傷図鑑(15) では高温スカッフィ ングと低温スカッフィングに分けて事例が示されてい る.

$3 \cdot 4 \cdot 1$ 焼付設計限界と設計パラメータ

〈設計の現状〉一般的にはフラッシュ温度あるいは バルク温度で設計する. 移動熱源を基にした Blok 理 論から導かれた歯面温度上昇の指標 ${ }^{(16)}$ があるが，い ずれも歯車の歯面摩擦および動力損失による温度上昇 値が基本になっている，低周速歯車では歯面摩擦，高 周速歯車では潤滑油かくはんあるいは加速仕事が温度 上昇の要因になる。しかし，かみあい歯面摩擦係数や
加速仕事を定量的に表現できる式が少ない. 〈対処〉歯面の潤滑状態 (D 值：歯面粗さと油膜厚 さの比)を基にした歯面摩擦係数 ${ }^{(17)} に$ 比例するフラッ シュ温度で焼付データを整理すると, 歯面スカッフィ ングの有無を判別できる可能性がある。また歯車歯面 温度の上昇を動力損失から求めていく方法もある。潤 滑油加速仕事などの動力損失予測式(18) を基に, 歯車 ブランク全体の温度上昇を数值計算する方法が示され ており(19)，熱源の大きさの計算に活用できる．実用上 は PV または fPV 值 (f：摩擦係数)を用いた実績に基 づく設計でも対処できる。

$3 \cdot 4 \cdot 2$ 焼付きの原因

〈設計の現状〉かみあい始めやかみあい終わりで生 じる焼付現象は，歯形干涉か局所的な温度上昇による ものか見分けがつきにくい，ほとんどは歯形や歯筋修 正量不足による干涉であるが，これを温度上昇と間違 うと対策を誤る。

〈対処〉低温スカッフィングをフラッシュ温度基準 で耐焼付設計をするのは無理であり，歯面の干渉量を 弾性変形量と仮定して求めた接触応力を基準にする必 要がある。一般的には塑性変形が生じる接触圧力にな る.この場合も PV 值実績で使用限界基準を求めるほ うが焼付損傷の未然防止につながる(20). 高温スカッ フィングに対してフラッシュ温度で設計していく場合 は, 前述した推奨式を用いる(12).

\section{$3 \cdot 5$ 歯面摩耗}

〈設計の現状〉無給油や潤滑油枯渴状態で歯車を運 転すると歯面に摩耗が生じる．歯面粗さの増大を伴わ ず滑らかに摩耗する場合の摩耗限界が暧昧である。一 般的には摩耗した歯の厚さ減少量に応じた曲げ応力の 変化に着目した強度設計を行う，歯先が尖るほど摩耗 した歯車を使用することもできる，歯形が大きく変化 するほど摩耗する歯車の設計手法がない.

〈対処〉かみあい歯面の荷重分布, 総すべり距離お よび潤滑状態に応じた比摩耗量が必要である，歯面の 比摩耗量は実際に歯車を運転して求めるしかないが, 事前の運転試験が困難な場合は境界潤滑や無給油での 一般的な比摩耗量値を用いる。歯車の設計に際して は，まず初期の歯車誤差に基づく歯面上の動的歯当た り解析を実施し, 繰返し数の進行に伴う歯面の摩耗量 増加(歯形, 歯すじ誤差変化)を逐次考慮しながら目標 繰返し数までの歯の形状変化と動的増加荷重の変化を 求める. 各繰返し数で歯の曲げ折損強度のチェックを 行っていけば, 許容の摩耗量あるいは許容繰返し数な どを設定することができる(21)。大気中，真空中および 水中で無給油使用する歯車もほほ同様に対処できる。 


\section{4. 設計計算の曖昧部分}

\section{$4 \cdot 1$ 歯面荷重分布}

〈設計の現状〉誤差がある歯車の歯面上(瞬間值は 同時接触線上の)荷重分布計算が曖昧である。規格計 算では設計の基準は公称トルクで行うが, 歯車の固有 誤差と軸, 軸受やケーシング変形に基づく誤差などの 考慮が曖昧になっている，厳密には静的あるいは動的 (作動状態)歯当たり解析が必要である.

〈対処〉基本的には歯車誤差として確実な歯面修正 量を基準に歯当たり解析を行う(8). その後, 誤差等級 や支持剛性などを考慮して歯当たり変化を求める.歯 当たり解析計算プログラムがない場合は, 各種の規格 設計にある片当たり係数や速度係数などを基に荷重増 分を考え，その場合の精度は悪いことを念頭におき， 設計安全率を大きくとってカバーするしかない.

\section{$4 \cdot 2$ 歯車かみあい起振力}

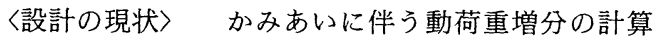
は，歯車の回転速度の影響を受ける。したがって歯車 の歯当たりを考慮した振動計算が必要になる．規格に ある速度係数などは不正確である。例えば同じ歯車誤 差等級で歯すじ, 歯形誤差を組合わせて動的解析した 例では(22), JIS 1 級の誤差で, 曲げ応力と接触応力で それぞれ最大 $65 \%$ ，255\%の違いが生じている。

〈刘処〉各種歯車誤差, 軸系, 軸受の条件を考慮し た解析を設計段階で行うべきである。誤差や支持剛性 に不安がある場合や重なりかみあい率が低い場合は計 算チェックしたほうがよい. 対処策は歯車の誤差パ夕 ーンを考慮した解析を行うことで, 解析技術の進展に 伴い最近再度この必要性が見值されてきた。

\section{$4 \cdot 3$ 歯面間潤滑油膜厚さ}

〈設計の現状〉歯面転動疲労設計の基準として, 歯 面間の潤滑状態を求める. 歯面粗さと油膜厚さの比で 評価する。しかし油膜厚さの計算値が曖昧である。 EHL 油膜厚さの計算式 ${ }^{(23)}$ の中で, 特に潤滑油の粘度 の影響が大きいが, 粘度を求める際の温度の值を合理 的に決められていない. 給油温度や排油温度など,い ろいろの基準が考えられているが，ぞれが正しいとい う根拠もない。

〈対処〉歯車箱の中は潤滑油の飛沫が充満してお り，給油分だけがかみあい面に入って行くとは考えら れない。歯車の本体(ブランク)温度を基準にする方法 もある。ブランク温度は歯車箱内の飛沫温度を測ると かなり正確に推定できる(24). 歯先円から $10 \mathrm{~mm}$ 程度 の位置に熱電対を設定して, 約 $5 \sim 10^{\circ} \mathrm{C}$ 低くなる程度 である。しかし新たに歯車を作る場合はそのような設
定が困難であるので，実用上は給油温度で油膜計算す るしかない。給油温度より低い場合はないので, 油膜 厚さが厚めに評価されることに留意する。なお油膜厚 さ計算式の精度に関して, 最近いろいろな数值計算方 法も提案されている( ${ }^{(25)}$ が, 計算結果は浪とんど変わ らない. 実用上は $0.1 \mu \mathrm{m}$ 以下の値を細かく計算して も意味はないが, 逆にそのオーダの計算精度もよくな いことに留意して対処する。

\section{5. 歯車システムの暧昧部分}

\section{$5 \cdot 1$ 動力伝達効率}

〈設計の現状〉＼cjkstart歯車装置の重要なパフォーマンスに 動力伝澾効率 (動力損失) が挙げられるが, 効率の評価 方法が曖昧である ${ }^{(26)}$. 歯車の効率は高く，どのような 平行軸歯車装置でも $98 \%$ 以上はあると信じている設 計者が多い. 効率は入出力の比であるので, 大出力の 場合は効率が良くなる。その理由は，動力損失の中に トルクに依存する歯面摩擦仕事などの因子と, 回転速 度に依存する因子が混在していることにある、後者は 高周速域では回転するだけで大きな動力損失の主因と なる，その場合の動力伝達効率は非常に低くなる，最 悪の場合は駆動源の出力よりも損失が大きくなり起動 不能となる。また多くの歯車設計者は, 軸受(特にす べり軸受)の損失計算を確実に行わない場合があるの で注意が必要である。

〈対処〉前述した提案されている有効な動力損失予 測式(18) はあるので, 動力損失を計算し歯車装置の回 転速度に応じた伝達効率を把握する。伝達効率の保証 値を設定する場合は，使用条件を明確にして対処す る. 特に低トルク高速, 大トルク低速条件での効率表 現に注意する。

\section{$5 \cdot 2$ 騒音予測}

〈設計の現状〉歯車騷音低減ニーズは非常に大きい が, 騒音予測の方法が曖昧である。設計段階で, 図面 諸元から騷音レベルを表現する方法がない。試作し て, 運転すれば, 騒音源となるかみあい起振力の低減 程度から, 騒音低減対策は可能となるが, 試作なしに 騒音予測は困難である。

〈対処〉類似の伝達動力, 歯車精度, 運転条件など の情報を集め, 経験的な騒音レベル情報を把握してお く必要がある。試作が容易な場合は，種々の解析を行 うよりも運転で騷音レベルを把握することをスタート にしたほうがよい、歯車箱の音響エネルギーなどを解 析で求める方法もあるが, 音響の波長と構造解析での 解析格子間隔をマッチングさせにくい点もあるので注 意が必要である．歯車箱の振動モードを近似できない 
場合がある。

\section{$5 \cdot 3$ 装置寿命}

〈設計の現状〉歯車装置を含む機械装置全体の寿命 とリスク評価のためにも，歯車装置の寿命に対する考 えを明確にしておかねばならない，寿命計算を行える 転がり軸受を使う歯車装置で, 転がり軸受の寿命が歯 車装置の寿命で, 歯車は無限寿命と考える間違いもよ く行われている.転がり軸受と同じ転動要素である歯 車が，無限寿命と考える機械業界の考え方を是正して いかねばならない。

〈対処〉歯車の寿命が有限で, 寿命自体も確率表現 すべきであることを認識する，規格設計ではそこまで 細かい表現は不要な場合もあると思うが, 自社製品の 損傷デー夕を分析し，損傷確率表現のためのデー夕蓄 積を進めていかねばならない。

\section{$5 \cdot 4$ 歯車寸法の影響}

〈設計の現状〉 小形機械, MEMS 用として小モジ ユール歯車の使用機会が増えている。法が小さいた めに生じる課題が未解明なまま, 小形歯車の強度, 寸 法設計がなされている，歯車の曲げ強度に対しては， 歯元隅肉部曲率半径が極めて小さく, 応力集中係数と 切欠係数の関係が十分に解明されていない.またかみ あい歯面の相対曲率半径が小さくなると, 従来の応力 体積の考え方によれば, 同じ接触応力のもとでは転動 疲労寿命は上昇しなければならないが, どうなるのか 末解明である。また小さな相対曲率半径のかみあい歯 面に形成される潤滑油膜厚さは非常に小さく, 通常の 表面粗さとの比で転動寿命を議論してよいか，さらに は潤滑油の歯車に対する吸着力の影響を考えなくてよ いかが, 未解明となっている.

〈対処〉 小モジュール歯車の歯元曲げ疲労に関して は応力解析を行えば対処できそうであるが, 切欠係数 を求める作業が残っている，転動疲労に関しては，転 動面が油膜で分離されない場合は相対曲率半径が 0.1 $\mathrm{mm}$ 程度までは, 従来の転動疲労寿命の考えが適用て きる(27). 歯面が油膜で分離される場合は, 寿命が長く なる可能性があるが, 未解明である。現状では，寸法 が小さい場合に同一接触応力で生じる転動疲労損傷寿 命を長くとることは危険である。さらに小形歯車の転 動疲労ピットは弾性接触域が小さいためにサイズが小 さい.そのためピットの発生が歯車の使用限界になら ない場合がある。

\section{$5 \cdot 5$ 軸継手}

〈設計の現状〉継手の選定条件が曖昧である。ほと んどの歯車装置は, 原動機と出力側に継手を設ける. 継手の拘束条件は，歯車かみあい条件へ影響する．特
に歯車継手を使うと, 継手のがたが非線形挙動となる ため, 振動挙動に影響してくる。

〈対処〉継手の拘束条件の歯当たりへの影響も考え た設計図面にする。弾性継手を多用する設計者もいる が, 無用の高価な継手を付ける必要はない. 最近は歯 車継手の非線形挙動を解析で考慮できるようになって いる(28)ので, 継手の最適化は歯車システムの重要課 題と認識し設計項目に入れる必要がある。

\section{$5 \cdot 6$ なじみ運転および試運転}

〈設計の現状〉なじみ運転の条件が曖昧である。ど のような条件で運転すればなじみが出るか, 単なる無 負荷運転でよいのかなどの課題が解決されていない. 基本的に完全ななじみは定格トルクを加え枚得られ ないが，実用上はある程度のトルクをかけた負荷運転 が必要である. トルクの大きさで歯当たりが決まるこ とを考えれば, 歯当たり領域のなじみにトルクが必要 なことはすぐに理解できる.

〈対処〉なじみ運転は歯面分離が起こらないトルク 条件で行う。おおむね定格の $20 \%$ 以上のトルクであ れば歯面分離は防げる．無負荷運転で歯面を衝突させ ながら行う試験は無意味であるので注意が必要であ る、転がり軸受支持であれば, 軸受の軽負荷運転も転 動面に公転すべりが生じるスキッディングを誘発し て, 軸受焼付きにつながる恐れがある.なじみ運転の 真の目的は, 転動疲労ピットの起点になる運転初期の 表面粗さ干渉によるき裂の除去あるいは塑性変形によ る進展阻止にあることに留意する。

\section{$5 \cdot 7$ メンテナンスと異常検知}

〈設計の現状〉歯車装置のメンテナンスは, 一般的 には润滑油や軸受の交換時期を設定する程度で，その 根拠は暧昧である。 また歯車の異常検知は振動, 温度 に関する測定デー夕を基に実施される。これらの手法 での検知は自動計測に必要であるが, 損傷を伴う歯車 の異常は熟練作業者なら五感で容易に検知できる。し かし，異常が検知できないまま，定期検査で点検した 際に歯面ピッチングや歯の欠損が破認され，損傷対策 に入る場合が多い。従来の異常検知方法では検知でき ない微小な変化に着目した異常の予兆検知手法が必要 となっている.

〈対処〉歯車や軸受の異常予兆検知は従来の振動や 温度に関する信号処理に工夫を施す必要がある。従来 の波形の振幅管理に加え, 波形形状変化管理を行うこ とにより, 予兆の検知が可能となる可能性が大きい. 波形形状管理の一例として運転振動波形のフラクタル 次元変化に着目する方法 ${ }^{(29)}$ がある。 


\section{6. 終わりに}

説明した項目以外にも，歯車設計には曖昧な点が多 い.しかし曖昧部分が解決しなければ設計できないと いうわけではない.わからなくても設計，製作しなけ ればならない. 多くは各メーカの経験値で対処するこ とで克服できると思うが, 製作や運転経験がないとこ ろは解析技術で追い込むしかない. 設計コンセプトの 曖昧な部分の克服には，経験と解析の両立しかなく， 規格設計では対処できない. 今後は，本稿で述べた曖 昧な事象に関する運転実験による現象解明が進むこと を期待したい.

最後に歯車の研究は長年実施されてきて，もう研究 することがないと詔認されている，多くの研究機関や 大学で歯車研究を行わなくなってきたのは, 技術が飽 和した陳腐な研究領域とされているためである。しか し多くの機械システムの進展は機械を構成する部品や 機械要素の進展なしにはあり得ない. 現実に歯車の使 用限界向上のニーズは大きい(30). 歯車装置も使用限 界や使用範囲の拡大が今後の大きな課題である。現 在, 日本機械学会産官学連携センタ一研究協力事業委 員会にて「歯車装置の使用範囲拡大のための設計・製 造技術に関する調査研究分科会」が設置されている。 調查研究の進展を期待したい.

\section{文献}

(1) ANSI/AGMA 2001-C 95 Fundamental Rating Factors and Calculation Methods for Involute Spur and Helical Gear Teeth, (2001-1).

(2) ANSI/AGMA 6110-F 97 Standard for Spur, Helical, Herringbone and Bevel Enclosed Drives, (1997).

(3) AGMA 215.01 Information Sheet for Surface Durability (Pitting) of Spur, Helical, Herringbone and Bevel Gear Teeth, (1966).

(4) AGMA 218.01 AGMA Standard for Rating the Pitting Resistance and Bending Strength of Spur and Helical Involute Gear Teeth, (1982).

(5) ISO 6336 Calculation of Load Capacity of Spur and Helical Gears, Part 2: Calculation of Surface Durability (Pitting), Part 3: Calculation of Tooth Bending Strength, (1996).

(6) ISO 6336-6 Calculation of Load Capacity of Spur and Helical Gears, Part 5 : Strength and Quality of Materials, (2003).

(7) ISO/DIS 6336-6 Calculation of Load Capacity of Spur and Helical Gears, Part 6: Calculation of Service Life under Variable Load, (2004).

(8) Matsumoto, S. et al., Application of Tooth Contact Analysis (in Japanese), Machine, Vol. 48, No. 8 (1996), pp. 847-854, Yokendo Ltd.

(9) Kaneta, M. and Yamamoto, Y., Fundamental Machine Design (in Japanese), (1995), pp. 24-26, Rikougakusya Ltd.

(10) The Japan Society of Mechanical Engineers ed.,
RC 205 (Research Committee on the Innovation in Practical Technology of Power Transmission Gearing Systems), Final Report (in Japanese), (2005), pp. 5997.

(11) Matsumoto, S., Improvement of Tooth Surface Durability of Heavy Duty Large Gears (in Japanese), $D r$. Thesis, (1982), pp. 110-112, Kyushu Univ.

(12) Nakamura, H. et al., Problems in Estimation of Fatigue Durability (in Japanese), Vol.21, No.227 (1972), pp. 725-732.

(13) The Japan Society of Mechanical Engineers ed. RC 218 (Research Committee for Improvement of Power Transmitting Capability and Proactive Measure against Gear System's Trouble), Final Report (in Japanese), (2007), pp. 64-80.

(14) Ishibashi, T., Prevention of Fatigue and Breakage of Metas (in Japanese), (1967), pp. 52-61, Yokendo Ltd.

(15) The Japan Society of Mechanical Engineers ed., Gear Failure-A Pictorial Guide - (in Japanese), (2006), pp. 113-128.

(16) The Japan Society of Mechanical Engineers ed., Data Book-Gear Load Capacity- (in Japanese), (1979), pp. 75-84.

(17) Matsumoto, S. et al., Temperature Distribution in Teeth and Blanks of Ultra High-Speed Gears (2 nd Report), Transactions of the Japan Society of Mechanical Engineers, Series C, Vol.65, No. 630 (1999), p. 710.

(18) Matsumoto, S. et al., Evaluation Method of Power Loss in High-Speed Gears, Proceedings of the Japanese Society of Lubrication Engineers, International. Tribology Conference, (1985-7), pp. 1165-1170.

(19) Matsumoto, S. et al., Temperature Distribution in Teeth and Blanks of Ultra High-Speed Gears (2 nd Report), Transactions of the Japan Society of Mechanical Engineers, Series C, Vol. 65, No. 630 (1999), pp. 708-713.

(20) Shibuya, H. et al., Improvement of Winch Gears for Large Water Gate (in Japanese), Mitsubishi Heavy Industries Technical Report, Vol. 18, No. 4 (1981), pp. 1-7.

(21) Matsumoto, S., Gears for Extreme Environmental Condition (in Japanese), The Japan Society of Mechanical Engineers, RC 117 Report, (1995), pp. 1-10.

(22) The Japan Society of Mechanical Engineers ed., RC 205 (Research Committee on the Innovation in Practical Technology of Power Transmission Gearing Systems), Final Report (in Japanese), (2005), pp. 98100.

(23) Dowson, D., ELASTOHYDRODYNAMICS, Proceedings of the Institution of the Mechanical Engineers, Vol. 182, Pt 3 A (1967-68), pp. 151-167.

(24) Matsumoto, S. and Rikihisa, K., Scoring tests of HighSpeed Gears, Proceedings of the Japan Society of Mechanical Engineers, No.768-3 (1976-11), pp. 107109.

(25) Nakahara, T. et al., Special Issue on Trends of the Theory and Application about EHL, Journal of. Japanise Society of Tribologists, Vol.49, No. 4 (2004), pp. 275-308.

(26) Yada, T., Application of Gear Mechanisms (in Japanese), Science of Machine, Vol.51, No. 6 (1999), pp. 691-698.

(27) Yoshida, Y. et al., Effects of Size and Lubricating Condition on Rolling Contact Fatigue, Proceedings of Tribology Conference (Tokyo 2005), (2005-11), pp. 
437-438.

(28) Shoda, K. et al., Study on Non-limear Nimerical Simulation of Vibration of Power Transmission Gear System (2nd Report), Transactions of the Japan Society of Mechanical Engineers, Vol.71, No. 704 (2005), pp. 1153-1160.

(29) Okumura, K. et al., Middle Electrical Connection
Value of Rolling Contact Surfaces, Proceedings of the Tribology Conference (Tokyo 2005), (2005-11), pp. 459-460.

(30) The Japan Society of Mechanical Engineers ed., RC 184 (Research Committee on the Design and Production Techniques in Next Generation), Final Report (in Japanese), (2002), pp. 7-28. 